\title{
A Study on Normal and Nubbin Productivity of Some Mango Trees in Relation to Quantification of Expressed Gene Levels Abdel-Sattar, M. ${ }^{1}$; A. M. Ibrahim ${ }^{1}$; N. A. Ashmawy ${ }^{2}$ and E. Shams ${ }^{3}$ \\ ${ }^{1}$ Pomology Department, Faculty of Agriculture (El-Shatby), Alexandria Univ., Egypt. \\ ${ }^{2}$ Plant Pathology Department, Faculty of Agriculture (El-Shatby), Alexandria Univ., Egypt. \\ ${ }^{3}$ Extention Sector, Ministry of Agriculture and Land Reclamation, Giza, Egypt.
}

\begin{abstract}
The present investigation was carried out during 2015 and 2016 seasons on three Egyptian mango cultivars (Mangifera indica L.) named Ewais (normal \& nubbin), Sedeq and Zebda grown at a private orchard in Idko region under Beheira governorate conditions. The trees were selected to study normal and nubbin fruits of some mango trees productivity and quantification of expressed gene levels as well as trying to make better understanding of embryo abortion phenomenon in mango. Real-time qPCR was used to detect the relative amounts of mRNA of four different genes. Fruit physical characteristics of Ewais (nubbin) cultivar, i e fruit length, width and pulp, stone and peel weights, as well as yield were lower significantly than normal fruits, while its pulp/ stone ratio gave the highest values, in both seasons. The chemical characteristics of Ewais (nubbin), i e TSS, TSS/ acidity, reducing sugars, total sugars and pectin methyl esterase were significantly higher than normal fruits, while acidity, vitamin $\mathrm{C}$ and peroxidase were the lowest values. Results showed that the four selected ESTs were differentially expressed in the tissues of normal, aborted embryos and leaves, however, the 4 ESTs (MaAGA, MaAP2, MaERF, and MaMADS) were upregulated in normal embryo tissues compared to aborted embryos of "Ewais". Also the expression levels in the leaves tissues were upregulated in Sedeq and Zebda varieties compared to Ewais leaves. The results of total protein (SDS-PAGE) explained that Zebda and Sedeq cultivars, which had normal fruits gave the highest several bands in both embryos and leaves tissues than Ewais cultivar which had nubbin fruits.
\end{abstract}

Keyword:Mango, Mangifera indica, Real-time qPCR, Total protein (SDS-PAGE),Productivity.

Corresponding author:M. Abdel-Sattar Fax:+2035922780, Email: mahmoud.hassan @alexu.edu.eg.

\section{NTRODUCTION}

Mango (Mangifera indica L.) is a globally important fruit crop of the tropics and subtropics, particularly in Egypt, where it is considered the 'king of fruits' due to its delicate, sweet flavor and nutritional value. The total fruiting area of mango trees was about 88510 hectare that produced about 927350 ton at the year of 2014 (Arab Agricultural Statistics Yearbook, 2015). Only perfect (hermaphrodite) flowers are able to set fruit, however, the number of perfect flowers per inflorescence varies between cultivars or is variable from year to year, depending on the location of the inflorescence in the tree (Singh and Arora, 1965 and Singh, 2005).

Embryo abortion, which hinders normal fruit development, seems to play an important role in induction of the abscission process at early stages of fruit development (Mukherjee, 1953). Earlier studies and observations had focused on the physiological and anatomical aspects of mango embryo abortion, and the molecular basis of this disorder is unknown. In this regard, according to Bustin (2002), Real-time PCR differs from classical PCR by the measurement of the amplified PCR product at each cycle throughout the PCR reaction. In practice, a video camera records the light emitted by a fluorochrome incorporated into the newly synthesized PCR product. Thus, real-time PCR allows the amplification to be followed in real-time during the exponential phase of the run and thus allows the amount of starting material to be determined precisely.

It is necessary to identify the genes that are differentially expressed in aborted tissue to explore the molecular basis of embryo abortion in mango. Furthermore, He et al. (2012) used a PCR-based subtractive hybridization technique to isolate differentially expressed genes from normal and aborted embryo tissues to characterize the molecular aspects that probably play role in embryo abortion events. However, Choudhury et al. (2012)employed (SDSPAGE $10 \%$ ) markers to make an assay to systematically investigate the role of an AGAMOUS MADS-box transcription factor in regulation of fruit ripening and floral reproductive organ development in banana cultivar Giant governor. They reported that single distinct protein band with an approximate molecular mass near $27-\mathrm{kDa}$ was obtained in the elution fractions from both flower and fruit specific DNA-protein complexes.

The aims of the present study are to determine normal and nubbin productivity of some mango trees in relation to quantification of expressed gene levels. In addition to understand better embryo abortion phenomenon in some mango trees through obtaining the role of some ESTs genes that implicated in embryo abortion using RT-qPCR technique.

\section{MATERIALS AND METHODS}

The present investigation was carried out during two successive seasons 2015 and 2016 on three Egyptian mango cultivars (Mangifera indica L.) named Ewais (normal \& nubbin), Sedeq and Zebda grown in a private orchard in Idko region under Beheira governorate conditions. The experimental trees were about eight years old, budded on Sukkari rootstock, planted on sandy soil at $3 \times 5 \mathrm{~m}$ For the present study, twenty trees were selected as uniform as possible in vigor ( $\mathrm{i}$ e 4 accessions $\times 5$ replicates $=20$ trees) and under regular horticultural practices including: fertilization, pruning as well as pest and disease control. Flooding system was used for irrigation.

\section{Trees productivity}

In order to determine mango trees productivity, number of normal and nubbin fruits/ tree was counted and the yield in $\mathrm{Kg}$ was calculated by multiplying 
number of fruits per tree $X$ the average of fruit weight. Additionally, fruit physical and chemical characteristics were determined in samples collected randomly from each replicate(5 fruits) at the harvest date in 30 August for Ewais, 20 August for Sedeq and 25 July for Zebda in 2015 and 2016 seasons respectively, and directly transported to the laboratoryof the Faculty of Agriculture, Alexandria University.

\section{A. Fruit physical characteristics}

Average fruit length and diameter $(\mathrm{cm})$ were measured for each individual fruit using a Vernier caliper and fruit length /diameter ratio was calculated. Fruit, pulp and peel weight (g) were determined for each cultivar. Also, pulp / stone ratio was estimated in the fruit samples by weighing the stone and pulp then the fruit pulp / stone ratios were calculated.

\section{B. Fruit chemical characteristics}

In another sample of five fruits, juice from each replicate was used to determine the percentage of TSS by hand refractometer. Vitamin $\mathrm{C}$ was determined in 1 $\mathrm{ml}$ fruit juice by titration with 2,6dichlorophenolindophenol blue dye as $\mathrm{mg}$ ascorbic acid/100ml juice according to the AOAC (1995). Five $\mathrm{ml}$ from the obtained juice were used to determine the titratable acidity as g citric acid /100 ml juice according to the method described by Chen and Mellenthin (1981). The total reducing sugars \% was determined according to the method of Malik and Singh (1980). The reducing sugars were determined by the Nelson arsenate-molybdate colorimetric method (Dubois et al., 1956)

The peroxidase activity in fruits pulp was estimated using the method of Thomas et al. (1981). According to Matsuno and Uritani (1972) and Carvalho et al.(2015), enzyme activity was reported as enzymatic units (U) and is defined as the amount of enzyme that produces a change in absorbance of $1.0 / \mathrm{min}$ under the assay conditions at $25^{\circ} \mathrm{C}$. Extraction of pectin methyl esterase (PME) was as described by Lazan et al. (1989). Pectin esterase activity was assayed using a modification of the method of Lazan et al. (1995). The assay mixture (25.5 ml) comprising $\mathrm{Ca} 1 \%(\mathrm{w} / \mathrm{v})$ pectin containing $2.5 \mathrm{~m} \mathrm{~mol}$ $\mathrm{CaCl}_{2}$; and enzyme extract $(0.5 \mathrm{ml})$ was titrated $\left(25^{\circ} \mathrm{C}\right)$ with $0.01 \mathrm{M} \mathrm{NaOH}$ at $\mathrm{pH} 7.5$ for $15 \mathrm{~min}$.

\section{Statistical analysis}

The data obtained throughout this study were statistically analyzed by the analysis of variance as a randomized complete block design as explained by using the software package SAS 9.13 (Service Pack 4, 2002-2003). The means compared using the LSD test as differences at $P=0.05$ are considered significant.

\section{Quantification of expressed gene levels}

Leaves from the three cultivars and fresh fruits with aborted embryos from Ewais (nubbin) and normal fruits from all cultivars were collected after 15 days of fruit set in 2016 to use as target samples. Then after 30 days of fruit set normal fruits and leaves were collected from all cultivars for calibrating the gene expression.

\section{A. Real-time quantitative RT-qPCR}

Nucleic acid extraction protocol modified from Llanes et al. (2002) was applied. Gene expression using Real-time qPCR was used to detect the relative amounts of mRNA of four genes; the selected ESTs were AGAMOUS protein (MaAGA), MADS box protein (MaMADS), AP2D domain class transcription factor (MaAP2) and ethylene response factor (MaEFR). Results were normalized to gene Actin were designed based on the sequence of Actin from mango asreference gene according to $\mathrm{He}$ et al. (2012). Primers are illustrated in Table 1.

One step Real-time RT-qPCR analysis using 2x SensiFAST SYBR ${ }^{\circ}$ One-Step Kit master mix (BIOLINE) according to the manufacturer's instructions. The amplification program proceeded at $95{ }^{\circ} \mathrm{C}$ for 10 min, followed by 40 cycles of denaturation at $95{ }^{\circ} \mathrm{C}$ for $15 \mathrm{sec}$; annealing at $60^{\circ} \mathrm{C}$ for $30 \mathrm{sec}$ and extension at 72 ${ }^{\circ} \mathrm{C}$ for $30 \mathrm{sec}$. The reaction was performed using a Rotor-Gene 6000 (QIAGEN, ABI System, USA).Data analysis using relative expression ratio was accurately quantified and calculated as described by Livak and Schmittgen (2001).

\section{B. Total protein biochemical (SDS-PAGE) markers}

Sodium dodecyl sulphate polyacrylamide gel electrophoresis (SDS- PAGE) was carried out using the discontinuous buffer system as described by Sambrook et al. (1989). After the run was completed, the gel was stained as described by Hames and Rickwood (1990).

Table 1. Sequences of primers for Real-time quantitative PCR (RT-qPCR).

\begin{tabular}{lclc}
\hline Primers & Accession No. & $\begin{array}{l}\text { Nucleotide sequence 5' to 3 } \\
\text { (F=Forward, R=Reverse) }\end{array}$ & Reference \\
\hline MaAGA & JK513220 & F:AGAGATGGGGAGAGGAAAAATT & \\
& & R:CGGCTGGAGAAGACAATGAG & \\
MaMADS & JK513593 & F:GGGGGTTCCTGTTCTCTCTT & He et al. $(2012)$ \\
MaAP2 & \multirow{2}{*}{ JK513603 } & F:GGGCTCTCTCTTTGCTTTCTCT & \\
MaERF & JK513364 & F:GCGCTGCCTTATTCCTCTGTA & \\
& & R:CCATAAATCAGCCGAGTAACAGT & \\
\hline
\end{tabular}

\section{RESULTS AND DISCUSSION}

\section{Trees productivity}

\section{A. Fruit physical characteristics}

The data presented in Table 2 cleared that Zebda cultivar had significantly higher yield per tree than the other cultivars, while Ewais (nubbin) cultivar had lowest yield in both seasons. Additionally Sedeq cultivar had significantly heavier fruit, pulp,stone and peel weight than the other cultivars in both seasons. Meanwhile, Ewais (nubbin) cultivar had lowest values in both seasons. In addition, Ewais (nubbin) recorded 
the highest significant pulp/ stone ratio as compared to the other cultivars, while Zebda had the lowest total pulp/ stone ratio. In both seasons, Sedeq cultivar had significantly longer fruits length than the other cultivars in both seasons, while Ewais (nubbin) cultivar had the lowest fruit length and width. No significant difference was found between Zebda and Sedeq cultivars in fruit width in the first season, while Sedeq cultivar had higher fruit width than Zebda.

It was noted that the variations in fruit physical characteristics (normal or nubbin) and among the studied cultivars could be due to the variability in the genetic structures. The observed data concurred with those mentioned by Shaban and Ibrahim (2009) whereas, trees of all evaluated cultivars produced higher significant yield of normal fruit than nubbin fruit. Also, Shaban (2005), Boshra (2009), El-Khawaga and Maklad (2013) and Elsheshetawy et al.(2016), who measured the physical properties of six cultivars from Sharkia and Ismailia region and Ibrahim et al. (2016), who studied genetic diversity on some polyembryonic\& monoembryonic mango genotypes using morphological and molecular markers.

\section{B. Fruit chemical characteristics}

The results in Table 3 indicated that nubbin and normal Ewais had significantly higher juice reducing and total sugars and TSS percentage TSS / acidity ratio as compared to the other cultivars in both seasons, while the remained cultivars had the lowest ones. In addition, Zebda and Sedeq cultivars had significantly higher juice acidity as compared to the other cultivars in both seasons. Sedeq cultivar had significantly higher juice vitamin $\mathrm{C}$, while Ewais (nubbin) cultivar the lowest ones. Zebda cultivar had the significantly higher peroxidase activity (POD) than the other cultivars, while Ewais (nubbin) cultivar the lowest one. On contrary, Ewais (nubbin) cultivar had the significantly higher pectin methyl esterase (PME) than the other cultivars, while Zebda had cultivar the lowest one.

These outcomes were in harmony with those of Hamdard et al. (2004) and Anjum et al. (2014), who evaluated chemical contents of eight mango cultivars. It was clearly obtained that the variations in the chemical characteristics like total sugars, reducing sugars, TSS, acidity, the ratio between TSS / acidity, vitamin C, peroxidase activity and pectin methyl esterase of fruit (normal or nubbin) and among the studied cultivars could be due to the variability in the genetic structures.

Table 2. Yield and fruit physical characteristics of three mango cultivars Ewais (normal and nubbin), Sedeq and Zebda during 2015 and 2016 seasons.

\begin{tabular}{|c|c|c|c|c|c|c|c|c|c|c|c|c|}
\hline \multirow[t]{2}{*}{$\begin{array}{c}\text { Cultivars } \\
\text { (accessions) }\end{array}$} & \multicolumn{2}{|c|}{$\begin{array}{c}\text { Yield } \\
\text { (Kg/ tree) }\end{array}$} & \multicolumn{2}{|c|}{$\begin{array}{c}\text { Fruit } \\
\text { weight(g) }\end{array}$} & \multicolumn{2}{|c|}{$\begin{array}{c}\text { Pulp weight } \\
\text { (g) }\end{array}$} & $\begin{array}{c}\text { Stone } \\
\text { weight (g) }\end{array}$ & \multirow{2}{*}{\multicolumn{3}{|c|}{ 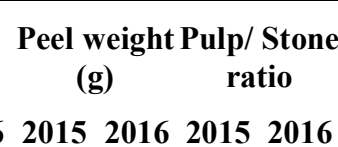 }} & \multirow{2}{*}{$\begin{array}{l}\text { e Fruit } \\
\text { length }(\mathrm{cm}) \\
20152016 \\
\end{array}$} & \multirow{2}{*}{$\begin{array}{l}\text { Fruit } \\
\text { width } \\
(\mathbf{c m}) \\
20152016\end{array}$} \\
\hline & 2015 & 2016 & 2015 & 2016 & 2015 & 2016 & 20152016 & & & & & \\
\hline $\begin{array}{l}\text { Ewais } \\
\text { (Normal) }\end{array}$ & 61.62 & 56.64 & 251.58 & 247.40 & 184.02 & 182.50 & 34.7832 .58 & 33.6832 .54 & 5.34 & 5.64 & 10.7610 .60 & 6.005 .82 \\
\hline $\begin{array}{l}\text { *Ewais } \\
\text { (Nubbin) }\end{array}$ & 2.73 & 2.78 & 78.42 & 76.92 & 55.84 & 55.50 & 5.30 & 16.9216 .14 & +12.68 & 310.60 & 6.30 & $4.42 \quad 4.48$ \\
\hline Sedeq & 51.18 & 54.40 & 534.94 & 537.66 & & 421.78 & 54.2452 .94 & 66.3662 .92 & 7.78 & 8.00 & 15.5815 .68 & 7.948 .10 \\
\hline Zebda & 89.70 & 83.86 & 380.20 & 377.06 & 268.02 & 273.24 & 51.3249 .18 & 60.8454 .62 & 5.30 & 5.60 & 12.7212 .28 & 8.027 .36 \\
\hline $\mathrm{LSD}_{0.05}$ & 6.11 & 4.77 & 22.26 & 19.52 & 21.319 & 19.32 & $3.57 \quad 2.34$ & $4.86 \quad 3.29$ & 4.28 & 0.82 & $\begin{array}{ll}0.73 & 0.72 \\
\end{array}$ & $\begin{array}{ll}0.39 & 0.21 \\
\end{array}$ \\
\hline
\end{tabular}

Table 3. Fruit chemical characteristics of three mango cultivars Ewais (normal and nubbin), Sedeq and Zebda during 2015 and 2016 seasons.

\begin{tabular}{|c|c|c|c|c|c|c|c|c|c|}
\hline \multirow[t]{2}{*}{$\begin{array}{c}\text { Cultivars } \\
\text { (accessions) }\end{array}$} & $\begin{array}{c}\text { Total } \\
\text { sugars }(\%)\end{array}$ & $\begin{array}{c}\text { Reducing } \\
\text { sugars } \\
(\%)\end{array}$ & $\begin{array}{l}\text { TSS } \\
(\%)\end{array}$ & $\begin{array}{c}\text { Acidity } \\
(\%)\end{array}$ & $\begin{array}{c}\text { TSS/acidity } \\
\text { ratio }\end{array}$ & $\begin{array}{c}\text { Vitamin C } \\
\text { (mg/100 ml } \\
\text { juice) }\end{array}$ & $\begin{array}{c}\text { POD } \\
\text { (U/gm) }\end{array}$ & \multicolumn{2}{|c|}{$\begin{array}{c}\text { PME } \\
(\mathbf{U} / \mathbf{m l})\end{array}$} \\
\hline & & & & & & 20152016 & & & \\
\hline & 1.9413 .46 & 7.10 & 19.0020 .20 & 0.690 .60 & & 58.7062 .20 & & & \\
\hline (15) & 12.5813 .90 & 7.367 .06 & 20.5022 .00 & $0.60 \quad 0.52$ & 34.6643 .60 & 39.9645 .54 & $0.66 \quad 0.64$ & 158.46 & 157.66 \\
\hline & & 5.32 & & & & & 782 & & \\
\hline & $\begin{array}{ll}78 & 10.1\end{array}$ & 5.14 & 14.1815 .50 & 0.770 & & 57.5659 .66 & 3.483 & & \\
\hline 0.05 & $1.19 \quad 0.88$ & $0.63 \quad 0.90$ & $2.10 \quad 2.21$ & $0.13 \quad 0.16$ & $\begin{array}{ll}6.67 \quad 9.38 \\
\end{array}$ & $5.11 \quad 6.31$ & $0.05 \quad 0.04$ & 3.225 & 3.51 \\
\hline
\end{tabular}

2. Quantification of expressed gene levels

A. Real-time quantitative PCR (RT-qPCR)

The data representing the relative expression ratio was accurately quantified as in Figures (1-4) and calculated according to the algorithm $2^{\wedge}(-\Delta \Delta \mathrm{Ct})$ and outcomes are listed in Table (4).The results explained that Zebda and Sedeq cultivars, which had normal fruits had the highest ratio (fold) of AGAMOUS (MaAGA), MADS box (MaMADS), AP2 domain (MaAP2) and ethylene response factor (MaERF) protein than the other cultivar (Ewais), which had a nubbin fruits (aborted) in both of embryos and leaves tissues. 
Table 4. Gene expression of mango embryos from Zebda, Sedeq and Ewais (normal and nubbin) cultivars and leaves using RT-qPCR.

\begin{tabular}{lccc}
\hline Target Genes & Cultivars & $\begin{array}{c}\text { Embryos } \\
\mathbf{2}^{\wedge}(-\Delta \Delta \mathbf{c t}) \\
\text { (fold) }\end{array}$ & $\begin{array}{c}\text { Leaves } \\
\mathbf{2}^{\wedge}(-\Delta \Delta \mathbf{c t}) \\
\text { (fold) }\end{array}$ \\
\hline \multirow{2}{*}{ MaAGA } & Ewais & 0.03 & 0.71 \\
& Sedeq & 1.43 & 5.76 \\
\multirow{3}{*}{ MaMADS } & Zebda & 1.82 & 22.5 \\
& Ewais & 0.03 & 0.42 \\
& Sedeq & 1.09 & 1.92 \\
MaAP2 & Zebda & 2.04 & 20.5 \\
& Ewais & 0.04 & 0.04 \\
& Sedeq & 1.28 & 0.48 \\
MaERF & Zebda & 2.55 & 0.63 \\
& Ewais & 0.04 & 1.50 \\
& Sedeq & 1.42 & 2.10 \\
& Zebda & 2.43 & 9.51 \\
\hline
\end{tabular}

These findings referred to increasing in gene expression of AGAMOUS in the cultivars, which had normal fruit than the aborted one and illuminated the role of AGAMOUS in fruit development and floral organ identity which controlled by diverse families of homeotic transcription factors, the floral homeotic gene AGAMOUS (AG) is a group $\mathrm{C}$ gene and it encodes a MADS box transcription factor as explained by Yanofsky et al.(1990). These findings pointed to expanding in gene expression of MADS box in the cultivars, which had normal fruit than the aborted one and represented the role of MADS box in fruit as master regulators of flowering transition and development of flowers, fruits, and seeds as recorded by Ma et al. (2011) and Hemming and Trevaskis (2011). Also, Genome-wide studies suggest that most MADS-box genes are expressed in a variety of organs and cell types at different developmental stages as reported by Rijpkema et al. (2007). Loss-of-function mutations in multiple $M A D S$-box genes can convert floral organs to leaf-like structures, and ectopic expression of $M A D S$ box genes can convert leaves into floral organs, illustrating the critical role $M A D S$-box genes play during floral development as mentioned by Trevaskis et al.(2007).

These outputs referred to the increasing in gene expression of AP2D domain class transcription factor (MaAP2) in the cultivars, which had normal fruit than the aborted one and represented the role of AP2D domain transcription factor in fruit development and ripening. However, the deduced amino acid sequences of ERFs comprise a conserved DNA-binding ERF/AP2 domain (ranging from 58 to 59 amino acids), which is characteristic of the plant ERF gene family as described by Liu et al. (2010). The 17 ERFs share a highly conserved ERF/AP2 domain with ERF proteins of other plants, proving that the 17 ERFsencode the ERF family $\mathrm{TF}$ in the mango fruit, and the cDNA sequences obtained from the RNA-seq are credible according to Hoang et al. (2015).

These outputs referred to the increasing in gene expression of ethylene response factor (MaEFR) in the cultivars which had normal fruit than the aborted one and represented the role of ethylene response factor (MaEFR) in fruit development and ripening. Moreover, Aharoni and O'Connell (2002) isolated a plant specific transcription activation factor associated with ethylene and abscisic acid response (ERF) from strawberry and suggested its involvement in late achene development. High expression of this gene suggested that it is one of the key transcription factors involved in multitude of activities. Also, ethylene response factor (MaERF) may play an important role in cell resistance to infections and degradation as illuminated by Hoang et al. (2015).

\section{B. Total protein biochemical (SDS-PAGE) markers} 1. Embryos

The SDS-PAGE $15 \%$ image of total protein electrophoresis in embryos for the studied mango cultivars were marked and figured in Figure (5-A). The results showed that each cultivar had several numbers of bands were arranged in a descending order: $8,7,5$ and 3 bands for Zebda, Sedeq, Ewais (normal) and Ewais (nubbin) cultivars, respectively. These results defined that the highest numerous and intensity bands were $(8$ bands) in Zebda cultivar followed by ( 7 and 5 bands) in Sedeq and Ewais (normal), respectively. While the lowest multiples were ( 3 bands) in Ewais (nubbin) cultivar. The bands were with an approximate molecular mass ranged from $(28-\mathrm{kDa}$ to $74-\mathrm{KDa})$ were obtained in the elution fractions of protein from embryos.

\section{Leaves}

The SDS-PAGE $15 \%$ image of total protein electrophoresis in leaves for the studied mango cultivars were marked and figured in Figure (5-B). The results showed that each cultivar had several numbers of bands arranged in a descending order: 6,5 and 4 bands for Zebda, Sedeq and Ewais cultivars, respectively. These results defined that the highest numerous and strengthens bands were (6 bands) in Zebda cultivar followed by ( 5 bands) in Sedeq. While lowest multiples were ( 4 bands) in Ewais cultivar. The bands with an approximate molecular mass ranging from $(27-\mathrm{kDa}$ to73-KDa) were obtained in the elution fractions of protein from leaves.

The results explained that the Zebda and Sedeq cultivars which had normal fruits had the highest several bands than Ewais cultivar which had nubbin (aborted) fruits, these were supported to the above described results where, there were high genes expression for all the experimented ESTs primers, especially in cultivars which had the normal fruits and that is reflected on the protein electrophoresis with more bands essentially in normal fruits.

These results agreed with other investigator as $\mathrm{He}$ et al. (2012) who evaluated the gene expression using subtractive suppression hybridization to investigate the differentially expressed genes involved in embryo abortion of mango fruit cv. 'Jinhuang'. Seven candidate genes from different categories were selected for semi-quantitative PCR analysis, and their possible functions in embryo abortion. They found that many transcriptionally regulated genes differentially accumulated in 2 types of mango embryo. However, 4 ESTs (MaAGA, MaAP2, MaERF, and $M a M A D S$ ) were upregulated in normal embryo tissues compared to aborted embryos. 


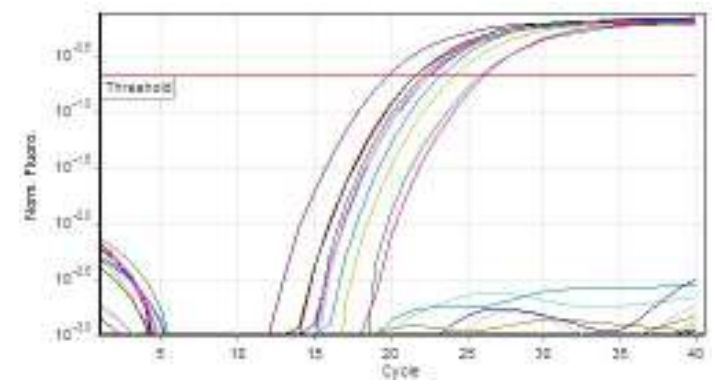

Figure 1. Amplification plot of fluorescent signal versus cycle number measured during quantitative amplification of AGAMOUS protein (MaAGA) by RT-qPCR.

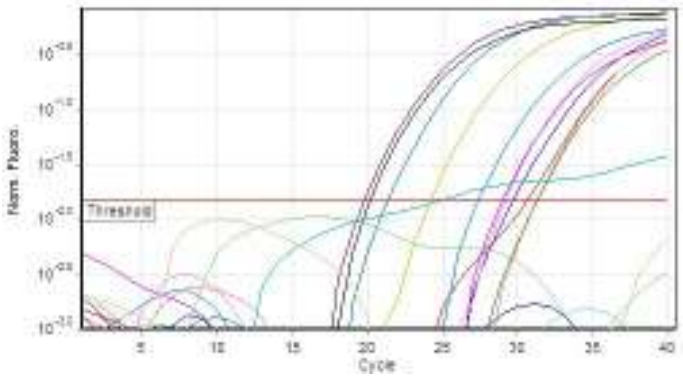

Figure 3. Amplification plot of fluorescent signal versus cycle number measured during quantitative amplification of AP2D domain class transcription factor protein (MaAP2D) by RT-qPCR.

A

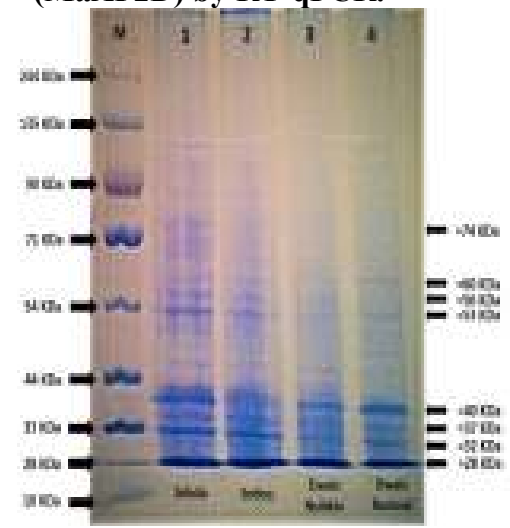

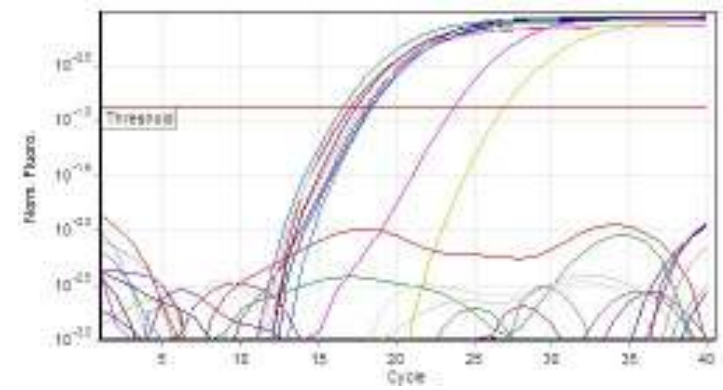

Figure 2. Amplification plot of fluorescent signal versus cycle number measured during quantitative amplification of MADS box protein (MaMADS) by RT-qPCR.

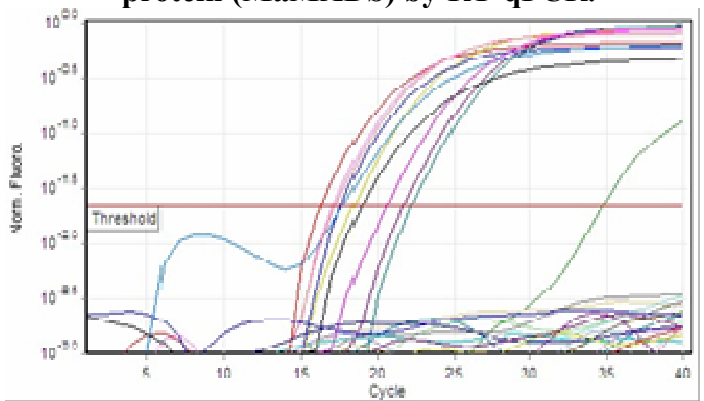

Figure 4. Amplification plot of fluorescent signal versus cycle number measured during quantitative amplification of ERF ethylene response factor protein (MaERF) by RT-qPCR.

B

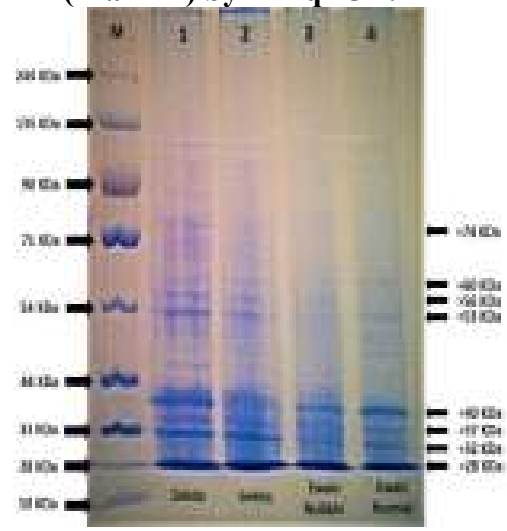

Figure (5 A\&B). SDS-PAGE of (A) total protein of mango embryos Zebda, Sedeq and Ewais (normal and nubbin) cultivars, (B) total protein of leaves from Zebda, Sedeq and Ewais (normal and nubbin) cultivars. The bands were calibrated with molecular marker ranging from 10 to $244 \mathrm{kDa}$.

\section{CONCLUSION}

This study suggests that relative quantification data provide basic ESTs and a step forward in our understanding of gene function and regulatory pathways belonged to embryo abortion in some mango cultivars.

\section{REFERENCES}

Aharoni, A. A. and P. O'Connell (2002). Gene expression analysis of strawberry achene and receptacle maturation using DNA microarrays. J. Exp. Bot., 53: 2073-2087.
Anjum, M. A.; S. S. Akhtar and B. Siddique (2014). Physcio- chemical sensory profiling of promising mango cultivars grown in Peri- Urban areas of Multan - Pakistan. Pak. J. Bot., 46(1): 191-198.

AOAC (1995). Official Methods of Analysis, $13^{\text {th }}$ Ed., Association of Official Analysis Chemists, Washington, D.C., USA.

Arab Agricultural Statistics Yearbook (2015). Arab Organization of Agricultural development, Part Ш, Vol., 35.

Boshra, E. S. (2005). Production of mango Nubbins "Ewais Cultivar" under environmental conditions of Assiut. Egyptian J. Hort., 32(1): 33-40. 
Bustin, S. A., (2002). Quantification of mRNA using real-time reverse transcription PCR (RT-PCR): trends and problems. J. Mol. Endocrinol., 29: 2339.

Carvalho, J. M.; G. A. Maia; A. V. V. Da Fonseca; P. H. M. De Sousa and S. Rodrigues (2015).Effect of processing on physicochemical composition, bioactive compounds and enzymatic activity of yellow mombin (Spondias mombin L.) tropical juice. J. Food Sci. Tech., 52(2):1182-1187.

Chen, P. M. and W. M. Mellenthin (1981). Effects of harvest date on ripening capacity and postharvest life of 'd'Anjou' pears. J. Amer. Soc. Hort. Sci., 106: 38-42.

Choudhury, R. S.; S. Roy; A. Nag; S. K. Singh and D. N. Sengupta (2012). Characterization of an AGAMOUS-like MADS box protein, a probable constituent of flowering and fruit ripening regulatory system in banana. PLOS ONE 7(9): e44361.

Dubois, M.; K. A. Cilles; J. K. Hamilton; P. A. Rober and F. Smith (1956). Colorimetric method for determination of sugar and related substances. Anal. Chem., 28: 350-356.

El-Khawaga A. S. and M. F. Maklad (2013). Evaluation of growth and productivity of some mango varieties grown under Aswan climatic conditions. Sinai J. Applied Sci., 1(2):169-178.

Elsheshetawy, H. E.; A. Mossad; W. K. Elhelew and V. Farina (2016). Comparative study on the quality characteristics of some Egyptian mango cultivars used for food processing. Annals Agric. Sci., 61(1): 49-56.

Hamdard, M. S; M. R. Rafique and U. Farooq (2004). Physcio-chemical characteristics of various mango (Mangifera indica L.) varieties. J. Agric., 42 (2): 191 - 199.

Hames, B. D. and D. Rickwood (eds.) (1990). Gel Electrophoresis of Proteins-A Practical Approach. IRL, Oxford University Press, Oxford.

He, J. H.; F. W. Ma; Y. Y. Chen and H. R. Shu (2012). Differentially expressed genes implicated in embryo abortion of mango identified by suppression subtractive hybridization. Genetics and Molecular Res., 11 (4): 3966-3974.

Hemming, M. N. and B. Trevaskis (2011). Make hay when the sun shines: the role of MADS-box genes in temperature-dependant seasonal flowering responses. Plant Sci., 180: 447-453.

Hoang, T. V. L.; D. J. Innes; P. N. R. Shaw; G. Monteith; M. J. Gidley and R. G. Dietzgen (2015). Sequence diversity and differential expression of major phenylpropanoidflavonoid biosynthetic genes among three mango varieties. BMC Genomic. 16: 561-573.

Ibrahim, A. M. F.; A. M. Attla; N. A. Awad; H.M.ELShishatawy and S. A. Ali (2016).Genetic diversity studied on some polyembryonic\& monoembryonic mango genotypes using morphological and molecular markers. Alex. J. Agric. Sci., 61 (1):111.
Lazan, H.; Z. M. Ali; K. S. Liang and K. L. Yee (1989). Polygalaeturonase activity and variation in ripening of papaya fruit with tissue depth and heat treatment. Physiol. Plant 77: 93-98.

Lazan, H.; M. K. Selamat and Z. M. Ali (1995). $\beta$ Galactosidase, polygalacturonase and pectinesterase in differential softening and cell wall modification during papaya fruit ripening. Physiol. Plant, 95: $106-112$.

Liu, J. X.; J. Y. Li; H. N. Wang; Z. D. Fu and J. Liu (2010). Identification and expression analysis of ERF transcription factor genes in petunia during flower senescence and in response to hormone treatments. J. Exp. Bot., 62: 825-840.

Livak, K. J. and D. T. Schmittgen (2001). Analysis of relative gene expression data using real-time quantitative PCR and the $2-\Delta \Delta \mathrm{Ct}$ method. Methods, 25: 402-408.

Llanes, K.; G. Gonzalez; B. C. Manzanero and D. Infante (2002). A rapid and simple method for small scale DNA extraction in Agavaceae and other tropical plants. Plant Molecular Bio. Rep., 20(3): 299a-299e.

Ma, C.; Y. Wang; Y. Wang and L. Wang (2011). Identification of a sugar beet BvM14-MADS box gene through differential gene expression analysis of monosomic addition line M14. J. Plant Physiol., 168: 1980-1986.

Malik, C.P. and M.P. Singh (1980). Plant Enzymology and Histo Enzymology. A Text Manual pp. 276277.

Matsuno, H. and I. Uritani (1972). Physiological behavior of peroxidase isoenzymes in sweet potato root tissue injured by cutting or with black rot. Plant Cell Physiol., 13(6):1091-1101.

Mukherjee, S. K. (1953). The mango: its botany, cultivation, uses and future improvement, especially as observed in India. Econ. Bot., 7: 130-162.

Rijpkema, A. S.; T. Gerats and M. Vandenbussche (2007). Evolutionary complexity of MADS complexes. Curr. Opin. Plant Biol., 10: 32-38.

Sambrook, J.; E. F. Fritsch and T. Maniatis (1989). Molecular Cloning: A laboratory manual, 2nd ed. Cold Spring Harbor Laboratory Press, Cold Spring Harbor, NY, (in 3 volumes).

SAS Institute Inc. (2008). The SAS System for Windows, Version 9.13, SAS Institute Inc., Cary, NC, USA. Singh, Z. and L. Singh.

Shaban, A. E. A., (2005). Effect of gibberellic acid spraying on inducing nubbin fruit of some mango cultivars. I: Fruit physical and chemical traits. Egypt. J. Appl. Sci., 20(5B): 761-776.

Shaban, A. E. A. and A. S. A. Ibrahim (2009). Comparative study on normal and nubbin fruits of some mango cultivars. Australian J. of Basic and Applied Sci., 3(3): 2166-2175.

Singh, R. and K. S. Arora (1965).Some factors affecting fruit drop in mango (Mangifera indica L.). Indian J. Agr. Sci., 35: 196- 205. 
Singh, Z. (2005). Embryo abortion in relation to fruit size, quality, and concentrations of nutrients in skin and pulp of mango. J. Plant Nut., 28, 1723 1737

Thomas, R. L.; J. J. Jen and C. V. Morr (1981). Changes in soluble and bound peroxidase, IAA oxidase during tomato fruit development. J. Food Sci., 47:158-161.

Trevaskis, B.; M. Tadege; M. N. Hemming and W. J. Peacock (2007). Short vegetative phase-like MADS-box genes inhibit floral meristem identity in barley. Plant Physiol., 143: 225-235.
Yanofsky, M. H.; H. Ma; J. L. Bowman; G. N. Drews and K. A. Feldman (1990). The protein encoded by the Arabidopsis thaliana homeotic gene agamous resembles transcription factors. Nature, 346: 35-39.

\section{دراسة على إنتاجية الثمار الطبيعية والفص لبعض أشجار المانجو وعلاقتها بمستويات التعبيز الجينى كميا

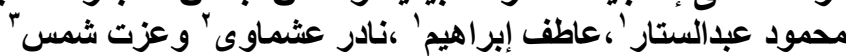

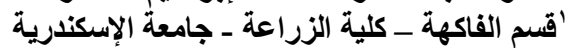

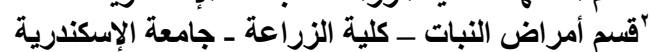

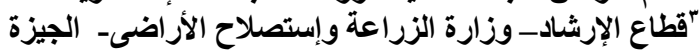

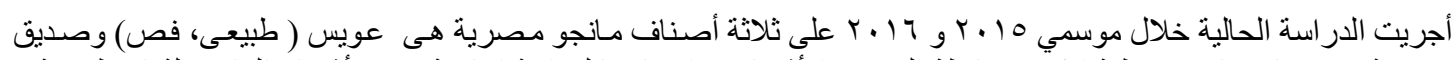

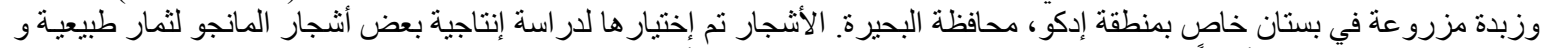

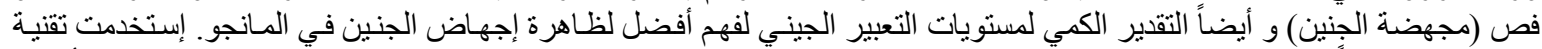

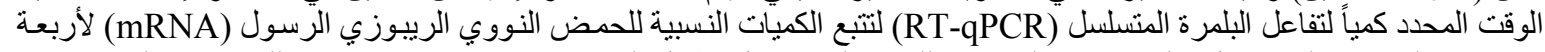

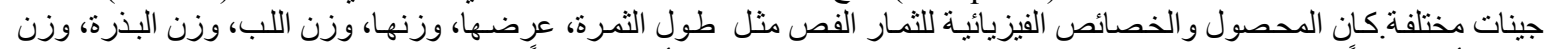

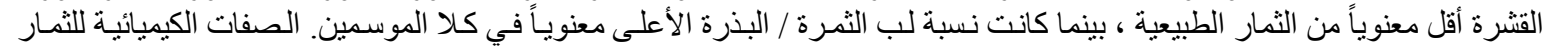

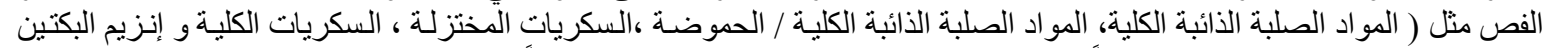

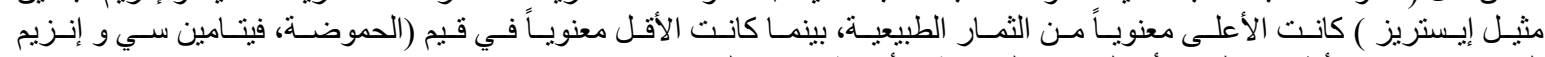

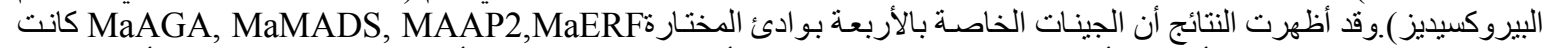

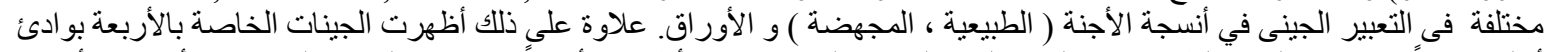

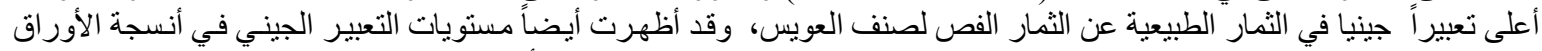

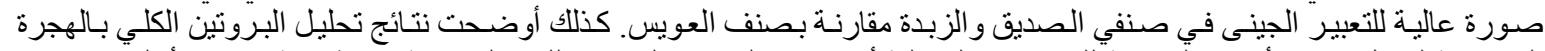

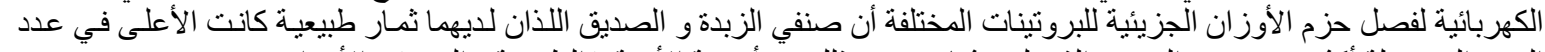
الحزم المفصولة أكثر من صنف العويس الذي لديه ثمار فص وذللك في أنسجة الأجنة ( الطبيعية ، الفصدة) والأور اق. لأن. 